DE

M E D I C I N A

T R O P I C A L

$\mathrm{DE}$

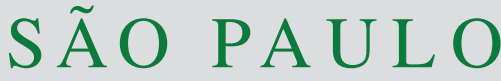

JOURNAL OF THE SÃO PAULO INSTITUTE OF TROPICAL MEDICINE

'Universidade Federal Fluminense, Niterói, Rio de Janeiro, Brazil

${ }^{2}$ Instituto Oswaldo Cruz, Fundação Oswaldo Cruz, Rio de Janeiro, Rio de Janeiro, Brazil

${ }^{3}$ Universidade Federal do Paraná, Curitiba, Paraná, Brazil

${ }^{4}$ Universidade Federal do Rio de Janeiro, Rio de Janeiro, Rio de Janeiro, Brazil

${ }^{5}$ Universidade Federal do Estado do Rio de Janeiro, Rio de Janeiro, Rio de Janeiro, Brazil

${ }^{6}$ Programa de Controle da Tuberculose, São Gonçalo, Rio de Janeiro, Brazil

${ }^{7}$ Programa de Controle da Tuberculose, Itaboraí, Rio de Janeiro, Brazil

${ }^{8}$ Universidade Federal de Minas Gerais, Belo Horizonte, Minas Gerais, Brazil

${ }^{9}$ Fundação Hospitalar do Estado de Minas Gerais, Belo Horizonte, Minas Gerais, Brazil

${ }^{10}$ Hospital Municipal Raphael de Paula Souza, Rio de Janeiro, Rio de Janeiro, Brazil

${ }^{11}$ Hospital Federal dos Servidores do Estado, Rio de Janeiro, Rio de Janeiro, Brazil

Correspondence to: Roberta Feijó

Carvalho

R. Cel. Moreira César, 26, sala 1207, Icaraí, CEP 24230-060, Niterói, RJ, Brazil

Tel: +55 21 2704-4941

E-mail: drarobertafeijo@gmail.com

Received: 29 June 2020

Accepted: 1 October 2020

\section{Diagnosis of pulmonary tuberculosis in children and adolescents: comparison of two versions of the Brazilian Ministry of Health scoring system}

Roberta Feijó Carvalho ${ }^{\circledR 1}$, Anna Cristina Calçada Carvalho ${ }^{\circledR 2}$, Luis Guillermo Coca Velarde ${ }^{\circledR} 1$, Andrea Maciel de Oliveira Rossoni ${ }^{\circledR 3}$, Rafaela Baroni Aurilio ${ }^{\circledR} 4$, Selma Maria de Azevedo Sias ${ }^{\circledR}$, Christiane Mello Schmidt ${ }^{\circledR}$, Adriana da Silva Rezende Moreira ${ }^{\circledR 4}$, Pedro da Silva Martins ${ }^{\circledR 2}$, Lorrayne Isidoro Gonçalves ${ }^{{ }^{2}}$, Terezinha Miceli Martire ${ }^{\circledR 5}$, Ana Paula Ferreira Barbosa ${ }^{\circledR 6}$, Ana Paula Quintanilha dos Santos ${ }^{\circledR 7}$, Roberta Maia de Castro Romanelli ${ }^{\circledR 8}$, Maria das Graças Rodrigues de Oliveira ${ }^{\circledR 8}$, Lilian Martins Oliveira Diniz ${ }^{\circledR 9}$, Andrea Lucchesi de Carvalho ${ }^{\circledR 9}$, Sheila Cunha Lucena ${ }^{\circledR 10}$, Maria Letícia Santos Cruz ${ }^{\circledR 11}$, Mariza Curto Saavedra ${ }^{\circledR 11}$, Tony Tannous Tahan ${ }^{\circledR 3}$, Cristina de Oliveira Rodrigues ${ }^{\circledR 3}$, Afrânio Lineu Kritski $^{\oplus}{ }^{4}$, Clemax Couto Sant'Anna ${ }^{\odot} 4$, Claudete Aparecida Araújo Cardoso ${ }^{\oplus}$, Maria de Fátima Bazhuni Pombo Sant’Anna ${ }^{\circledR} 4$

\section{ABSTRACT}

The aim of this study was to evaluate the concordance between two versions of the scoring system (2011 and 2019), recommended by the Brazilian Ministry of Health, for the diagnosis of pulmonary tuberculosis (PTB) in children and adolescents. A retrospective descriptive study was performed to assess the medical records of children and adolescents with PTB, in TB units from Brazilian cities located in Rio de Janeiro, Minas Gerais, and Parana States, from January $1^{\text {st }}, 2004$, to December $1^{\text {st }}, 2018$. Patients aged 0 to 18 years old with a diagnosis of PTB were included. The comparison between the two scoring systems showed a moderate concordance according to the $\kappa$ coefficient value $=0.625$. Fourteen patients showed a reduction in the TB score, going from 30 points in the 2011, to 25 points or less in the 2019 one. Seventy one percent of these 14 patients had radiological changes suggestive of PTB and $86 \%$ had tuberculin skin tests greater than $10 \mathrm{~mm}$. The study concluded that a moderate agreement was observed between the 2011 and 2019 scoring systems, with an increase in the number of patients scoring 25 points or less in 2019, which can eventually hinder the diagnosis of PTB.

KEYWORDS: Pulmonary tuberculosis. Children. Diagnosis. Clinical protocols. Tuberculin skin test. Tuberculosis scoring system.

\section{INTRODUCTION}

The World Health Organization (WHO) estimated 1.0 million new cases of tuberculosis (TB) in children younger than 14 years old in $2017^{1}$. Of these, $55 \%$ went undiagnosed and/or unreported. One possibility for this under-detection is the difficulty in TB diagnosis. In 2018, Brazil reported 75,709 new cases of TB, including $3.3 \%$ in children younger than 14 years old ${ }^{1}$.

Brazil is among the 30 countries with a high burden of TB and coinfections of Mycobacterium tuberculosis (Mtb) and the human immunodeficiency virus (HIV) 
are considered a priority by the WHO for TB control in the world ${ }^{2}$.

The diagnosis of pulmonary TB (PTB) in children is challenging as childhood TB is paucibacillary, symptoms are nonspecific, and in the early stages of the disease up to $50 \%$ of children can be asymptomatic ${ }^{3-6}$.

Due to the difficulty of the bacteriological confirmation of TB in children, in 2002, the Ministry of Health, Brazil $(\mathrm{MoH})$ recommended the use of a scoring system (score) for the diagnosis of PTB in childhood ${ }^{7,8}$. The score comprises clinical, epidemiological and radiological data of evidence of infection by $M t b$ (positive tuberculin skin test [TST]) and it does not involve the bacteriological confirmation ${ }^{2,9,10}$. The use of this score helps the early diagnosis and treatment, even in basic health units ${ }^{2,11}$. This score has already had several validation studies published with consistent values of sensitivity and specificity that legitimized its use in the routine of health services ${ }^{2,3,12-15}$.

In the MoH TB Manual of 2011, the TST response was interpreted in accordance with the BCG vaccination time $^{16,17}$ (Table 1). The MoH TB Manual was revised in 2019 , and there was a change in the score because of the new interpretation of the TST cutoff point (Table 2) $)^{2}$. The TST is now interpreted as suggestive of infection by $M t b$ if a result of $5 \mathrm{~mm}$ or greater is present, regardless of the BCG vaccination time ${ }^{2}$. The scoring criteria in the $\mathrm{MoH}$ Manual are the same as those in 2011 and 2019, except for TST, but the total points achieved by a TST positive response in the new version of the score is 5 points lower than in the previous version ${ }^{2,16}$.

The present study aims to contribute to the diagnosis of childhood PTB by assessing the impact of the 2019 version of the $\mathrm{MoH}$ score for the diagnosis of PTB in children and adolescents. Therefore, there was interest in assessing whether this reduction in the total points of the score would influence the 2019 final scoring system, as the $\mathrm{MoH}$ recommends this scoring system for the diagnosis of PTB children.

\section{METHODS}

A retrospective descriptive study of medical records of children and adolescents from 0 to 18 years old was carried out, and the diagnosis of PTB was established based on clinical or laboratory criteria, in reference centers as well as in basic health units in Brazilian cities located in Rio de Janeiro State, such as Duque de Caxias, Niteroi, Itaborai and Sao Goncalo; Belo Horizonte in Minas Gerais State and Curitiba, in Parana State, in the period from January 2004 to December 2018.

All patients underwent evaluation using the 2011 $\mathrm{MoH}$ scoring system in their original health services.

Table 1 - Diagnosis of PTB in children and adolescents with negative smear ${ }^{16}$.

\begin{tabular}{|c|c|c|c|c|}
\hline Clinical condition & Radiological pattern & $\begin{array}{c}\text { Contact with adult with } \\
\text { TB }^{\star}\end{array}$ & $\mathrm{TST}^{\star}$ & Nutritional status \\
\hline $\begin{array}{l}\text { Fever or symptoms such } \\
\text { as cough, adynamia, } \\
\text { expectoration, slimming, } \\
\text { sweating }>2 \text { weeks } \\
15 \text { points }\end{array}$ & $\begin{array}{c}\text { Hilar adenomegaly or miliary } \\
\text { pattern and/or condensation } \\
\text { or infiltrate (with or without } \\
\text { cavitation) unchanged by } \geq 2 \\
\text { weeks and/or condensation } \\
\text { or infiltrate (with or without } \\
\text { excavation) for } \geq 2 \text { weeks, } \\
\text { progressing with worsening } \\
\text { or without improvement } \\
\text { with antibiotics for common } \\
\text { germs } \\
15 \text { points }\end{array}$ & $\begin{array}{l}\text { Close contact in } \\
\text { the last } 2 \text { years } \\
10 \text { points }\end{array}$ & $\begin{array}{c}\text { TST } \geq 5 \mathrm{~mm} \text { in not } \\
\text { vaccinated with Bacillus } \\
\text { Calmette-Guérin } \\
\text { (BCG), vaccinated for } \\
\text { more than } 2 \text { years, } \\
\text { immunosuppressed } \\
\text { or } \geq 10 \mathrm{~mm} \text { in children } \\
\text { vaccinated with BCG less } \\
\text { than } 2 \text { years ago } \\
15 \text { points }\end{array}$ & $\begin{array}{l}\text { Serious } \\
\text { malnutrition } \\
5 \text { points }\end{array}$ \\
\hline $\begin{array}{c}\text { Asymptomatic or with } \\
\text { symptoms }<2 \text { weeks } \\
0 \text { points }\end{array}$ & $\begin{array}{l}\text { Condensation or infiltrate of } \\
\text { any type for less than } \\
2 \text { weeks } \\
\mathbf{5} \text { points }\end{array}$ & $\begin{array}{l}\text { Occasional or } \\
\text { negative } \\
\mathbf{0} \text { points }\end{array}$ & $\begin{array}{l}\text { TST between } \\
0-4 \mathrm{~mm} \\
0 \text { points }\end{array}$ & 0 points \\
\hline $\begin{array}{l}\text { Respiratory infection } \\
\text { that improved after using } \\
\text { antibiotics for common } \\
\text { germs or without } \\
\text { antibiotics } \\
\text { (-10 points) }\end{array}$ & $\begin{array}{l}\text { Normal radiography } \\
(-5 \text { points })\end{array}$ & & & \\
\hline
\end{tabular}

${ }^{*}$ TB = tuberculosis; TST = tuberculin skin test. At least 40 points = very likely diagnosis; 30-35 points = possible diagnosis; Less than 25 points $=$ diagnosis is unlikely. 
Table 2 - Diagnosis of pulmonary tuberculosis in children and adolescents with negative smear microscopy or undetected RMT².

\begin{tabular}{|c|c|c|c|c|}
\hline Clinical condition & Radiological patterns & $\begin{array}{l}\text { Contact with adult } \\
\text { with } \mathrm{TB}^{\star}\end{array}$ & TST $^{*}$ & Nutritional status \\
\hline $\begin{array}{l}\text { Fever or symptoms such } \\
\text { as cough, adynamia, } \\
\text { expectoration, slimming, } \\
\text { sweating }>2 \text { weeks } \\
15 \text { points }\end{array}$ & $\begin{array}{l}\text { Hilar adenomegaly or miliary } \\
\text { pattern and/or condensation } \\
\text { or infiltrate (with or without } \\
\text { cavitation) unchanged by } \geq 2 \\
\text { weeks and/or condensation } \\
\text { or infiltrate (with or without } \\
\text { excavation) for } \geq 2 \text { weeks, } \\
\text { progressing with worsening } \\
\text { or without improvement } \\
\text { with antibiotics for common } \\
\text { germs } \\
15 \text { points }\end{array}$ & $\begin{array}{l}\text { Close contact in } \\
\text { he last } 2 \text { years } \\
10 \text { points }\end{array}$ & $\begin{array}{l}\text { TST between } \\
5 \text { and } 9 \mathrm{~mm} \\
5 \text { points } \\
\text { TST } \geq 10 \mathrm{~mm} \\
10 \text { points }\end{array}$ & $\begin{array}{l}\text { Serious } \\
\text { malnutrition } \\
5 \text { points }\end{array}$ \\
\hline $\begin{array}{c}\text { Asymptomatic or with } \\
\text { symptoms }<2 \text { weeks } \\
0 \text { points }\end{array}$ & $\begin{array}{l}\text { Condensation or infiltrate of } \\
\text { any type for less than } \\
2 \text { weeks } \\
\mathbf{5} \text { points }\end{array}$ & $\begin{array}{l}\text { Occasional or } \\
\text { negative } \\
\mathbf{0} \text { points }\end{array}$ & $\begin{array}{l}\text { TST }<5 \mathrm{~mm} \\
0 \text { points }\end{array}$ & $\begin{array}{l}\text { Weight } \geq 10^{\text {th }} \\
\text { percentile } \\
0 \text { points }\end{array}$ \\
\hline $\begin{array}{l}\text { Respiratory infection } \\
\text { that improved after using } \\
\text { antibiotics for common } \\
\text { germs or without } \\
\text { antibiotics } \\
\text { (-10 points })\end{array}$ & $\begin{array}{l}\text { Normal radiography } \\
(-5 \text { points })\end{array}$ & & & \\
\hline
\end{tabular}

RMT = rapid molecular test; TB = tuberculosis; TST = tuberculin skin test. At least 40 points (very likely diagnosis) = it is recommended to start TB treatment; $30-35$ points (possible diagnosis) = indicative of TB; it is advised to initiate treatment, at medical discretion; Less than 25 points (diagnosis is unlikely) = investigation of the child should be continued.

The 2011 score of patients diagnosed as having PTB was compared with those that would be obtained with the 2019 one. Diagnosis of PTB was confirmed by positivity of smear acid fast bacilli, Mtb culture or Xpert MTB/ RIF in 48 (39.0\%) of 123 patients undergoing diagnostic testing.

In the MoH TB Manual of $2011^{16}$, TST was considered positive if the skin induration was $\geq 5 \mathrm{~mm}$ in children not vaccinated with Bacillus Calmette-Guérin (BCG) vaccine, vaccinated for more than 2 years, or immunosuppressed, and $\geq 10 \mathrm{~mm}$ in children vaccinated with BCG in the previous 2 years, that scored 15 points. TST between 0 and $4 \mathrm{~mm}$ equals to zero points ${ }^{16,17}$.

In the MoH TB Manual of $2019^{2}$, regardless of BCG vaccination time, when the TST is $\geq 10 \mathrm{~mm}$, equals to 10 points. TST between 5 and $9 \mathrm{~mm}$, equals to 5 points. TST between 0 and $4 \mathrm{~mm}$ equals to zero points.

The studied variables were sex, age, TB symptoms, contact with an adult presenting with TB, chest X-ray, TST and the presence of malnutrition. The diagnostic criterion for malnutrition was weight below the $10^{\text {th }}$ percentile, according to $\mathrm{MoH}^{2,16}$. The human immunodeficiency virus infection was also investigated.

A descriptive statistics was used, and the agreement analysis was performed using the kappa $(\kappa)$ index to evaluate the two scores (2011 and 2019) and a dispersion graph was plotted.

This study was carried out in accordance with the Declaration of Helsinki and the Resolution 466/2012 of the Brazilian National Health Council of the Ministry of Health and was approved by the Research Ethics Committee of Oswaldo Cruz Institute -Fiocruz (coordinating center) on April 19 $9^{\text {th }}, 2017$.

\section{RESULTS}

The sample consisted of 235 patients with PTB diagnosed in their original health services using the 2011 score. One hundred and three patients $(52.3 \%)$ had a bacteriological/molecular test done and $39 \%$ of them (48/123) had a positive result. If we consider the total population, only $20.4 \%$ had a laboratory-confirmed diagnosis of TB (48/235).

Of the 11 health establishments involved in the study, three were primary care units, and the others were TB referral centers.

Most patients were female (56\%), and $64.7 \%$ were children (aged $<10$ years). Human immunodeficiency virus testing was performed in 135 (57.4\%) of the 235 patients, with $11(8.1 \%)$ of positivity. History of contact with an 
adult presenting with PTB, radiographic changes suggestive of PTB, and positive TST ( $>5 \mathrm{~mm}$ ) were recorded in most patients. The general characteristics of the patients, demographic and clinical aspects, and the diagnostic criteria for PTB are described in Table 3.

In our study, only one 8-month-old infant who had a TST of $9 \mathrm{~mm}$ received zero points in 2011, and 5 points in 2019 , reaching a final score varying from 40 to 45 points. Therefore, in 2019 this patient did not change the final

Table 3 - General characteristics of patients aged 0 to 18 years old diagnosed with pulmonary tuberculosis, from January 2004 to December 2019 (the total number of patients was 235).

\begin{tabular}{|c|c|c|}
\hline Characteristics & $\mathrm{N}$ & $\%$ \\
\hline \multicolumn{3}{|l|}{ Sex } \\
\hline Female & 131 & 56.0 \\
\hline Male & 104 & 44.0 \\
\hline \multicolumn{3}{|l|}{ Age (years) } \\
\hline$<2$ & 47 & 20.0 \\
\hline $2-9$ & 105 & 44.7 \\
\hline $10-14$ & 72 & 30.6 \\
\hline$\geq 15$ & 11 & 4.7 \\
\hline \multicolumn{3}{|l|}{ Symptoms } \\
\hline Absent & 74 & 31.4 \\
\hline$<2$ weeks & 9 & 3.8 \\
\hline$>2$ weeks & 150 & 63.8 \\
\hline $\begin{array}{l}\text { Improvement after antibiotic use or } \\
\text { without antibiotics }\end{array}$ & 2 & 1.0 \\
\hline \multicolumn{3}{|l|}{ Contact with TB } \\
\hline Negative & 41 & 18.0 \\
\hline Positive & 194 & 83.0 \\
\hline \multicolumn{3}{|l|}{ Chest X-ray } \\
\hline Changes suggestive of PTB & 202 & 86.0 \\
\hline Changes not suggestive of PTB & 19 & 8.0 \\
\hline Normal & 14 & 6.0 \\
\hline \multicolumn{3}{|l|}{ TST (in mm) } \\
\hline $0-4$ & 41 & 17.0 \\
\hline $5-9$ & 14 & 6.0 \\
\hline$\geq 10$ & 180 & 77.0 \\
\hline \multicolumn{3}{|l|}{ Malnutrition } \\
\hline Absent & 205 & 87.0 \\
\hline Present & 30 & 13.0 \\
\hline \multicolumn{3}{|l|}{ HIV } \\
\hline Negative & 124 & 92.0 \\
\hline Positive & 11 & 8.0 \\
\hline
\end{tabular}

ST $=$ tuberculin skin test. classification, i.e., continued to be in the category "very likely TB".

In the 2011 scoring system, 224 (95.3\%) of 235 patients had a score of 30 points or greater, referring to a very likely ( $\geq 40$ ) or possible (30-35) PTB diagnosis. In 2019, there were 210 patients $(89.3 \%)$ with 30 points or more.

In 2011, the median score was 40 (interquartile range [IQR], 40-55), with a mean of 43 (standard deviation \pm 11 ). In 2019, the median score was 40 (IQR, 35-50), with a mean of 39 (standard deviation \pm 10 ). The difference between the mean scores was 4.09 points.

The 2019 score was lower than the one obtained in 2011. The agreement between 2011 and 2019 score categories was $70.2 \%$; being lower in the age range of 2 to 9 yearsold $(63.1 \%)$ with respect to patients $<2$ years old $(72.9 \%)$ and $\geq 10$ years old $(77.4 \%)$. The $\kappa$ coefficient value was 0.625 , referring to a moderate agreement $(0.4 \leq \kappa<0.8)$. The scatter plot with the 2011 and 2019 scores is shown in Figure 1.

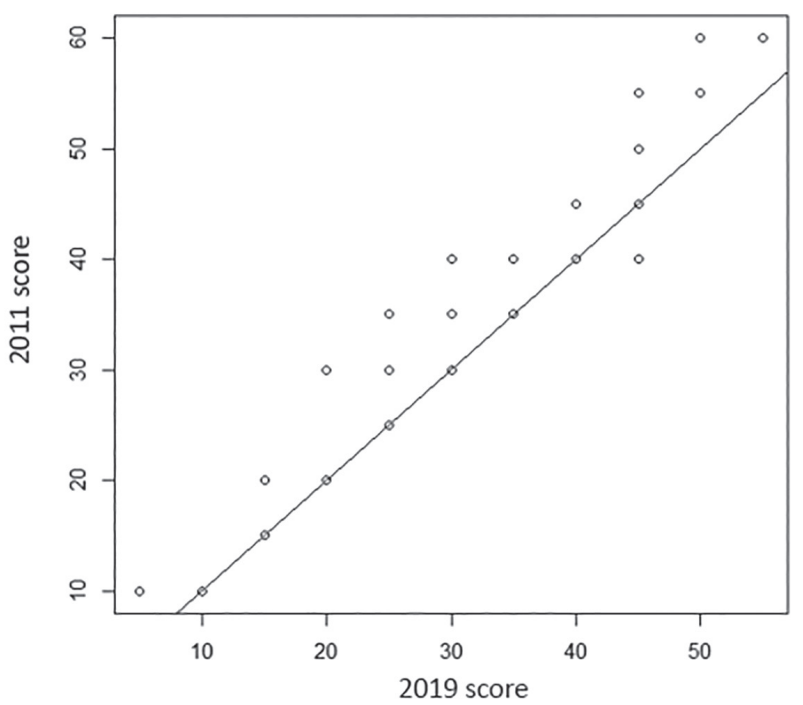

Figure 1 - Scatter plot with the comparison between the 2011 score and the 2019 one.

It was found that 14 patients had a score of 30 or more in 2011, while they would have a score of 25 or less (TB unlikely) using the 2019 scoring system. According to the 2011 score, 11 patients obtained 25 points or less.

The 11 patients with 25 or less by the 2011 score and the 14 patients who were evaluated with this score in 2019 were analyzed separately (Table 4).

The majority of these 14 patients who presented with a reduction in points, i.e., started to score 25 or less in 2019 , had radiological changes suggestive of TB (71.4\%) and a TST of $10 \mathrm{~mm}$ or greater $(86 \%)$. On the other hand, $86 \%$ were asymptomatic and $71.5 \%$ had no contact with an adult with TB. Regarding the HIV test, $43 \%$ were negative; 
Table 4 - Analysis of patients who scored 25 points or less (unlikely TB) in $2011(n=11)$ and $2019(n=14)$.

\begin{tabular}{|c|c|c|}
\hline \multirow{3}{*}{ Characteristics } & 2011 score & 2019 score \\
\hline & $\mathrm{n}=11$ & $\mathrm{n}=14$ \\
\hline & n (\%) & n (\%) \\
\hline \multicolumn{3}{|l|}{ Sex } \\
\hline Male & $3(27.0)$ & $6(43.0)$ \\
\hline Female & $8(73.0)$ & $8(57.0)$ \\
\hline Age (mean value in years) & 7.1 & 5.1 \\
\hline \multicolumn{3}{|l|}{ Contact with TB } \\
\hline Yes & $7(64.0)$ & $4(28.5)$ \\
\hline No & $4(36.0)$ & $10(71.5)$ \\
\hline \multicolumn{3}{|l|}{ Symptoms } \\
\hline No symptoms & $4(36.0)$ & $12(86.0)$ \\
\hline Symptoms $<2$ weeks & $1(9.0)$ & $2(14.0)$ \\
\hline Symptoms > 2 weeks & $6(55.0)$ & 0 \\
\hline \multicolumn{3}{|l|}{ Malnutrition } \\
\hline Yes & $4(36.0)$ & $1(7.0)$ \\
\hline No & $7(64.0)$ & $13(93.0)$ \\
\hline
\end{tabular}

none was positive, and $57 \%$ had no information about the HIV test.

In the 2019 score, there were approximately three times more asymptomatic patients and others presenting with symptoms for less than 2 weeks. On the contrary, there were less malnourished patients than with the 2011 score (Table 4).

The evaluation of these 14 patients has also shown that 5 of $11(45 \%)$ patients underwent tests for the diagnostic investigation with smear, culture, or polymerase chain reaction that showed positive results, confirming the TB diagnosis. All these 5 patients $(n=2,<2$ years old; $n=3$, $\geq 10$ years old and adolescents) who had microbiological positive results also had chest radiography results suggestive of PTB; TST of $10 \mathrm{~mm}$ or greater; no history of contact with a TB patient; malnutrition; or PTB suggestive symptoms.

\section{DISCUSSION}

The retrospective assessment of the 2011 and 2019 scores carried out in the present study showed a moderate agreement between both systems, as expressed by the $\kappa$ coefficient of 0.625 .

In the present study, 194 patients $(82.5 \%)$ were reported as having PTB by different health services, having had contact with an adult with $\mathrm{TB}$, thus reflecting the importance of researching these data for the diagnosis of childhood
$\mathrm{PTB}^{18}$. Tuberculosis in children is directly associated with the prevalence of the disease in adults. The risk of acquiring $M t b$ infection is higher in children living in regions in which there is a high prevalence of active TB, in houses with high population density and poor ventilation ${ }^{19}$.

The finding of $13.0 \%$ of cases with severe malnutrition may reflect the frequent consumptive nature of $\mathrm{TB}^{20}$. Malnutrition is associated with TB, both as a risk factor and a consequence of the illness. The consumptive nature of TB is related to both, anorexia and increased production of inflammatory cytokines, which lead to a catabolic state ${ }^{20}$.

Regular assessment of weight in childhood is essential. In the study of Marais et al. ${ }^{21}$ the identification of persistent cough associated with documented failure to thrive contributed to the diagnosis of PTB, with a sensitivity of $68.3 \%$, specificity of $80.0 \%$, and a positive predictive value of $82.0 \%$.

It is noteworthy that the 2011 scoring system has higher scores than the ones obtained in 2019. However, it is important to note that the increase in the number of cases that scored 40 or more to a score of 30-35 points did not affect the diagnosis of PTB, as 30 points or more would already be indicative of PTB, even allowing the beginning of TB treatment according to clinical criteria ${ }^{2}$.

The increase from 11 to 25 patients with a score of 25 or less, in the comparison between 2011 and 2019, resulted in a higher number of patients who would be considered to present with unlikely PTB in 2019. This apparent loss of diagnostic capacity of the 2019 scoring system would only result in expanding the indication to proceed with the investigation in these patients, as has been recommended since $2011^{16}$. However, it was evident, in the present study, that the group with 25 points or less had radiological patterns compatible with PTB and TST-positive in most cases, although with other characteristics less suggestive of PTB. Thus, the diagnosis of these patients would naturally be more difficult and would corroborate the indication of more detailed investigation ${ }^{2,16}$.

The study has some limitations. Firstly, we can mention the lack of information in some medical records regarding the HIV testing. Secondly, it is important to note that although the score is more applicable to health services with low technological density, such as outpatient clinics and basic health units, the patients included in the study were mostly from referral centers and they have a greater operational capacity for TB investigation, limiting the extrapolation of results found in other levels of care. Thirdly, the score is recommend for children who are generally unable to expectorate and are mostly sputum negative as well as adolescents with negative smear microscopy or undetected RMT. In the present study, all children had a 
clinical diagnosis of PTB. The majority of adolescents were smear microscopy or RMT-negative, as well, or had no sputum tested. Finally, the study only included participants who had already been diagnosed with PTB according to the 2011 scoring system. Therefore, the results should not be subjected to generalization for the usual clinical scenario, which would include a large proportion of patients who do not actually have PTB.

\section{CONCLUSION}

Despite the aforementioned limitations, the present study is a subsidy for the National TB Control Program regarding the diagnosis of Childhood PTB. We observed that the percentage of patients with 25 points or less in 2011 increased in 2019. The change in the 2019 score decreased the importance of TST as a diagnostic criterion for PTB, probably leading to a more specific and less sensitive score in comparison with 2011. However, a moderate agreement was observed when the two scores were analyzed. New studies are needed to evaluate the sensitivity, specificity and predictive values of the 2019 scoring system.

\section{ACKNOWLEDGMENTS}

The authors thank Samya Ladeira Viera, Bárbara Silveira Faria, Carla Fernandes dos Santos Lara, Ana Lúcia Miceli, Luíza Martins Vieira and Suzana Aparecida Greggi de Alcantara for data collection; and Fernanda Dockhorn Costa, Denise Arakaki, Daniele Maria Pelissari, and Patricia Bartholomay Oliveira from the National TB Control Programme, Brazil, for the critical review of the manuscript.

\section{AUTHORS' CONTRIBUTIONS}

RFC, MFBPS, CCS, CAAC had primary responsiblity for protocol development, the final data analysis and writing the manuscrip; RFC, MFBPS, CCS, CAAC, ALK, ACCC and AMOR participated in the enrollment of patients, analytical framework for the study and contributed to the writing of the manuscript; LGCV, RBA, SMAS, CMS, ASRM, PSM, LIG, TMM, APFB, APQS, RMCR, MGRO, LMOD, ALC, SCL, MLSC, MCS, TTT and COR were responsible for patient screening or contributed to the writing of the manuscript. All the authors agree in submitting the manuscript.

\section{CONFLICT OF INTERESTS}

None were declared.

\section{FUNDING}

CCS (grant $\left.\mathrm{N}^{\circ} 302973 / 2019-2\right)$ and CAAC (grant $\mathrm{N}^{\circ}$ 314042/2018-0) were supported by Conselho Nacional de Pesquisa e Desenvolvimento (National Council for Scientific and Technological Development).

\section{REFERENCES}

1. Tahan TT, Gabardo BM, Rossoni AM. Tuberculosis in childhood and adolescence: a view from different perspectives. J Pediatr (Rio J). 2020;96 Suppl 1:99-110.

2. Brasil. Ministério da Saúde. Secretaria de Vigilância em Saúde. Departamento de Vigilância das Doenças Transmissíveis. Manual de recomendações para o controle da tuberculose no Brasil. 2a ed. atual. Brasília: Ministério da Saúde; 2019.

3. Rossoni AM, Rossoni MD, Rodrigues CO. Critérios de pontuação para diagnóstico de tuberculose em crianças. Pulmao RJ. 2013;22:65-9.

4. David SG, Lovero KL, March MF, Abreu TG, Ruffino Netto A, Kristski AL. A comparison of tuberculosis diagnostic systems in a retrospective cohort of HIV-infected children in Rio de Janeiro, Brazil. Int J Infect Dis. 2017;59:150-5.

5. Gie RP, Beyers N, Schaaf HS, Nel ED, Smuts NA, van Zyl S, et al. TB or not TB? An evaluation of children with an incorrect initial diagnosis of pulmonary tuberculosis. S Afr Med J. 1995;85:658-62.

6. Cartaxo CG, Rodrigues LC, Braga CP, Ximenes RA. Measuring the accuracy of a point system to diagnose tuberculosis in children with a negative smear or with no smear or culture. J Epidemiol Glob Health. 2014;4:29-34.

7. Brasil. Ministério da Saúde. Fundação Nacional de Saúde. Tuberculose: guia de vigilância epidemiológica. Brasília: Ministério da Saúde; 2002.

8. Pedrozo C, Sant'Anna CC, March MF, Lucena SC. Efficacy of the scoring system, recommended by the Brazilian National Ministry of Health, for the diagnosis of pulmonary tuberculosis in children and adolescents, regardless of their HIV status. J Bras Pneumol. 2010;36:92-8.

9. March MF, Aurílio RB. Laboratorial diagnosis of childhood tuberculosis. Resid Pediatr. 2017;7 Suppl 1:27-31.

10. Sant' Anna, CC, Orfaliais CT, March MF, Conde MB. Evaluation of a proposed diagnostic scoring system for pulmonar tuberculosis in Brazilian children. Int J Tuberc Lung Dis. 2006;10:463-5.

11. Sant'Anna CC, Mourgues LV, Ferrero F, Balanzat AM. Diagnóstico e terapêutica da tuberculose infantil: uma visão atualizada de um antigo problema. J Pediatr (Rio J). 2002;78 Suppl 2:205-14.

12. Sant'Anna CC, Orfaliais CT, March MF. A retrospective evaluation of a score system adopted by the Ministry of Health, Brazil in 
the diagnosis of pulmonar tuberculosis in childhood: a case control study. Rev Inst Med Trop Sao Paulo. 2003;45:103-5.

13. Rossoni AM, Lovero KL, Tahan TT, Netto AR, Rossoni MD, Almeida IN, et al. Evaluation of pulmonary tuberculosis diagnostic tests in children and adolescents at a pediatric reference center. Pulmonology. 2020 In Press.

14. Maciel EL, Dietze R, Silva RE, Hadad DJ, Struchiner CJ. Avaliação do sistema de pontuação para o diagnóstico da tuberculose na infância preconizado pelo Ministério da Saúde, Brasil. Cad Saude Publica. 2008;24:402-8.

15. Pearce EC, Woodward JF, Nyandiko WM, Vreeman RC, Ayaya SO. A systematic review of clinical diagnostic systems used in the diagnosis of tuberculosis in children. AIDS Res Treat. 2012;2012:401896.

16. Brasil. Ministério da Saúde. Secretaria de Vigilância em Saúde. Departamento de Vigilância Epidemiológica. Manual de recomendações para o controle da tuberculose no Brasil. Brasília: Ministério da Saúde; 2011.

17. Sant'Anna CC. Diagnóstico da TB na infância e na adolescência. Pulmao RJ. 2012;21:60-4.
18. Sant'Anna CC, Santos MA, Franco R. Diagnosis of pulmonary tuberculosis by score system in children and adolescents: a trial in a reference center in Bahia, Brazil. Braz J Infect Dis. 2004;8:305-10.

19. Carvalho AC, Cardoso CA, Martire TM, Migliori GB, Sant'Anna CC. Epidemiological aspects, clinical manifestations, and prevention of pediatric tuberculosis from the perspective of the End TB Strategy. J Bras Pneumol. 2018;44:134-44.

20. Besen A, Staub GJ, Silva RM. Manifestações clínicas, radiológicas e laboratoriais em indivíduos com tuberculose pulmonar: estudo comparativo entre indivíduos HIV positivos e HIV negativos internados em um hospital de referência. J Bras Pneumol. 2011;37:768-75.

21. Marais BJ, Gie RP, Hesseling AC, Schaaf HS, Lombard C, Enarson DA, et al. A refined symptom-based approach to diagnose pulmonary tuberculosis in children. Pediatrics. 2006;118:1350-9. 